\title{
Mupirocin resistance in coagulase-negative staphylococci
}

\author{
S. CONNOLLY, W. C. NOBLE and I. PHILLIPS \\ Divisions of Dermatology and Microbiology, United Medical Dental Schools, St Thomas' Hospital Campus, \\ London SE1 7EH
}

\begin{abstract}
Summary. High-level mupirocin resistance in coagulase-negative staphylococci isolated from patients undergoing peritoneal dialysis was investigated by transfer of the resistance determinants, usually in the form of a plasmid, to Staphylococcus aureus strains, cleavage of the plasmid by restriction endonuclease and hybridisation with a probe comprising a $4.05 \mathrm{~kb}$ $E c o$ RI fragment of a plasmid from a $S$. aureus strain. In most instances the mupirocinresistant staphylococci isolated from each patient were different according to the species, antibiogram and plasmid profile data. The mupirocin resistance determinant was carried on various plasmids as judged by EcoRI restriction fragment length polymorphisms. All hybridised at about $4 \mathrm{~kb}$ with the $S$. aureus probe.
\end{abstract}

\section{Introduction}

Coagulase-negative staphylococci (CNS) are well established members of the normal flora of human skin $^{1}$ but are also evident in infection associated with indwelling catheters or prostheses. Control of such infection with the topical antibiotic Mupirocin (SmithKline Beecham) has been investigated. ${ }^{2-5}$ Although the rate of resistance to mupirocin in CNS has been reported to be c. $3 \%{ }^{6}$ there are few reports of specific studies. We have been particularly interested in infection in patients undergoing continuous ambulatory peritoneal dialysis (CAPD) and have collected staphylococci from the skin, nose and exit site of these patients. $^{7,8}$ In a continuing study of high-level resistance (MIC $>2000 \mathrm{mg} / \mathrm{l}$ ) to mupirocin, we have examined staphylococci from CAPD patients collected during 1987. A number of isolates proved to be resistant although the patients were not known to have received this antibiotic. This paper reports studies on these resistant staphylococci.

\section{Materials and methods}

\section{Staphylococci and cultural methods}

Bacterial strains and plasmids are listed in table I. Species were identified by conventional tests and the API STAPH and ATB32 STAPH kits (API bioMérieux, Basingstoke, Hants). Data on single isolates from patients $\mathrm{A}, \mathrm{By}$ and $\mathrm{V}$ have been partially described in a previous paper. ${ }^{9}$

Strains were routinely cultured on Blood Agar Base (BAB; Oxoid). Sensitivity testing was performed on Mueller-Hinton Agar (Oxoid) with Oxoid sensitivity

Received 11 Feb. 1993; accepted 21 May 1993. test disks as follows: Penicillin (Pc, $10 \mathrm{IU})$, tetracycline ( $\mathrm{Tc}, 30 \mu \mathrm{g}$ ), erythromcyin (Em, $15 \mu \mathrm{g}$ ), gentamicin (Gm, $10 \mu \mathrm{g}$ ), neomycin (Nm, $30 \mu \mathrm{g}$ ), mupirocin (Mup, $5 \mu \mathrm{g}, 200 \mu \mathrm{g})$, chloramphenicol (Cm, $30 \mu \mathrm{g})$. Minimum inhibitory concentrations (MICs) were measured by incorporating antibiotic in $\mathrm{BAB}$.

\section{Resistance transfer}

Resistance transfer was performed on filters and on the skin of hairless-obese mice as described previously. ${ }^{10}$ Plasmid DNA was prepared from the staphylococci by the method of Wilson et al. ${ }^{11}$ and from Escherichia coli by alkaline lysis. ${ }^{12}$ DNA was purified by caesium chloride-ethidium bromide density gradient centrifugation by standard methods ${ }^{13}$ and plasmid profiles were analysed by conventional or pulsed-field gel electrophoresis.

\section{Plasmid manipulation}

Plasmid DNA was digested with restriction endonuclease from Gibco BRL (Paisley) according to the manufacturer's instructions and analysed by conventional or pulsed-field gel electrophoresis in agarose in TBE buffer as described previously. Standards were $E$. coli strain V517 for intact plasmids ${ }^{13}$ and $\lambda$ phage cut by HindIII (Gibco BRL) for plasmid fragments.

Plasmids to be probed were digested with EcoRI, electrophoresed and transferred to a nylon membrane, either from Amersham (Slough, Berks) or Stratagene (Cambridge), according to the manufacturers' instructions.

\section{Probe construction}

Probe DNA was a 4.05-kb EcoRI fragment from an $S$. aureus plasmid ${ }^{14}$ cloned in $E$. coli JM 107 and was a 
Table I. Characteristics of coagulase-negative staphylococci

\begin{tabular}{|c|c|c|c|c|c|}
\hline $\begin{array}{l}\text { Code } \\
\text { no. }\end{array}$ & Source* & Species & Antibiogram $†$ & Plasmid profileł & $\begin{array}{c}\text { Number of } \\
\text { determinations } \$\end{array}$ \\
\hline A14E & Nose & S. epidermidis & $\mathrm{Pc}, \mathrm{Tc}, \mathrm{Em}$ & None detected & $9+1$ \\
\hline $\mathrm{B} \times 6$ & Exit & S. epidermidis & $\mathrm{Pc}, \mathrm{Tc}, \mathrm{Em}$ & $56,45,6,4 \cdot 6,2 \cdot 6$ & 4 \\
\hline $\mathbf{B} \times \mathbf{F}$ & Nose & S. epidermidis & $\mathrm{Pc}, \mathrm{Tc}, \mathrm{Em}$ & $55,45,6,4 \cdot 6,2 \cdot 6$ & 4 \\
\hline $\mathrm{B} \times 8$ & Exit & S. epidermidis & $\mathrm{Pc}$ & 45 & 2 \\
\hline $\mathbf{B} \times 13$ & Nose & S. epidermidis & $\mathrm{Pc}$ & 45 & $6+2$ \\
\hline B $\times 19$ & Exit & S. epidermidis & $\mathrm{Pc}$ & 45 & $4+1$ \\
\hline By Bi & Nose & S. epidermidis & $\mathrm{Pc}, \mathrm{Tc}$ & $40,11,6 \cdot 3,4 \cdot 7$ & 2 \\
\hline By Bii & Nose & S. capitis & $\mathrm{Pc}, \mathrm{Tc}$ & $57,7,2 \cdot 5$ & 2 \\
\hline By $\mathrm{Hi}$ & Nose & S. epidermidis & $\mathrm{Pc}, \mathrm{Tc}$ & $57,9,7 \cdot 5,4 \cdot 4$ & 2 \\
\hline By $\mathrm{Hii}$ & Nose & S. capitis & $\mathrm{Pc}, \mathrm{Tc}$ & $57,7,2 \cdot 5$ & 2 \\
\hline $\mathrm{Cs}$ & Nose & S. epidermidis & $\mathrm{Pc}, \mathrm{Em}$ & $45,2 \cdot 7$ & 4 \\
\hline D2 & Nose & S. haemolyticus & Pc, Tc & $4 \cdot 7$ & $2+2$ \\
\hline $\mathrm{E}$ & Exit & $S$. epidermidis & $\mathrm{Pc}$ & 45 & $6+2$ \\
\hline VB & Exit & S. epidermidis & $\mathrm{Pc}$ & 45 & $2+1$ \\
\hline $\mathrm{VC}$ & Exit & S. epidermidis & $\mathrm{Pc}$ & 45 & $2+1$ \\
\hline VD & Exit & S. hominis & $\mathrm{Tc}$ & $57,7 \cdot 4,3,2 \cdot 5$ & 2 \\
\hline $\mathrm{VE}$ & Exit & S. hominis & $\mathrm{Tc}$ & $57,7 \cdot 4,3,2 \cdot 5$ & $1+1$ \\
\hline $\mathrm{V} 3 \mathrm{E}$ & Exit & S. epidermidis & $\mathrm{Pc}$ & 45 & 2 \\
\hline V3F & Exit & S. hominis & Tc & $57,7 \cdot 4,3,2 \cdot 5$ & 2 \\
\hline V3J & Exit & S. epidermidis & $\mathrm{Pc}$ & 45 & $2+1$ \\
\hline
\end{tabular}

* Nose swab or CAPD exit site swab.

$\dagger$ Only resistances recorded, see text for antibiotics tested; all were resistant to mupirocin $\mathrm{MIC}>2000 \mathrm{mg} / \mathrm{L}$.

\$ Size in $\mathrm{kb}$ of intact plasmids seen by conventional gel electrophoresis.

$\S$ Number of determinations by conventional gel electrophoresis plus number by pulse-field gel electrophoresis.

Table II. EcoRI restriction fragment patterns from mupirocin-resistant transconjugants

\begin{tabular}{|c|c|c|}
\hline $\begin{array}{l}\text { Strain } \\
\text { no. }\end{array}$ & Species & Mean restriction fragment sizes \\
\hline $\mathrm{A} 14 \mathrm{E}(2)^{*}$ & S. epidermidis & $>25,13,10 \cdot 5,4,2.5$ \\
\hline Cs (4) & S. epidermidis & $11,6,5 \cdot 4,4,2 \cdot 6,2 \cdot 4,2 \cdot 3$ \\
\hline $\mathrm{D} 2(4) \dagger$ & S. haemolyticus & $11,10,5 \cdot 9,5 \cdot 4,4,2 \cdot 2,1 \cdot 8$ \\
\hline E (3) & & \\
\hline $\left.\begin{array}{l}\mathbf{B} \times 8(2) \\
\mathbf{B} \times 13(2) \\
\mathrm{B} \times 19(2)\end{array}\right\}$ & S. epidermidis & $11,9 \cdot 4,5 \cdot 4,4,2 \cdot 4,1 \cdot 8$ \\
\hline $\left.\begin{array}{l}\mathrm{B} \times 6(2) \\
\mathrm{B} \times \mathrm{F}(2)\end{array}\right\}$ & S. epidermidis & $11 \cdot 2,6,5 \cdot 6,5 \cdot 3,4,2 \cdot 7,2 \cdot 5,2 \cdot 3$ \\
\hline $\begin{array}{l}\text { By B1 (2) } \\
\text { By H (i) (3) }\end{array}$ & $\begin{array}{l}\text { S. epidermidis } \\
\text { S. epidermidis }\end{array}$ & $\begin{array}{l}15,8,5 \cdot 4,5 \cdot 3,4 \cdot 1,2 \cdot 5,2 \cdot 2,1 \cdot 7,1 \cdot 3 \\
15 \cdot 5,12,11,8,5 \cdot 7,4 \cdot 7,4 \cdot 2,2 \cdot 2,1 \cdot 4,1 \cdot 0\end{array}$ \\
\hline $\left.\begin{array}{l}\text { By B (ii) (3) } \\
\text { By H (ii) (3) }\end{array}\right\}$ & S. capitis & $15,11,10,7,4 \cdot 5,4 \cdot 3,4 \cdot 2,3 \cdot 0,2 \cdot 0,1 \cdot 4$ \\
\hline $\left.\begin{array}{l}\text { VC (2) } \\
\text { V3E (3) } \\
\text { V3J (2) }\end{array}\right\}$ & S. epidermidis & $16,8 \cdot 9,5 \cdot 7,5 \cdot 4,4 \cdot 3,3 \cdot 5,2 \cdot 5,2 \cdot 3,1 \cdot 4,1 \cdot 0$ \\
\hline $\left.\begin{array}{l}\text { VD (2) } \\
\operatorname{VE~(2)~} \\
V 3 F(2)\end{array}\right\}$ & S. hominis & $15,11,10,7,6,4 \cdot 5,4 \cdot 3,4 \cdot 1,2 \cdot 0,1 \cdot 0$ \\
\hline
\end{tabular}

* Transconjugant from isolate no. and (number of restrictions performed).
$\dagger$ Restriction digest of whole cell DNA showed bright bands.

gift from Dr. K. G. H. Dyke. Probe DNA was prepared by EcoRI digestion of recombinant DNA and the $4 \cdot 05-\mathrm{kb}$ fragment was recovered from the gel with Gene-clean II (Stratagene). The probe fragment was labelled with bio-11-dUTP/dTTP (Flash System, Stratagene), hybridised to blocked DNA at $43^{\circ} \mathrm{C}$ and visualised according to the manufacturer's instructions.

\section{Results}

A total of 403 isolates of CNS from 48 patients was screened and 20 isolates were found to be resistant to mupirocin $>2000 \mathrm{mg} / \mathrm{L}$. These 20 isolates were of four species, although most ${ }^{14}$ were $S$. epidermidis, and were from seven patients designated A, Bx, By, Cs, D, $\mathrm{E}$ and V. Patients Bx, By and V each carried two or 
more different species or apparently different strains of S. epidermidis as judged by antibiogram and plasmid profile (table I). With two exceptions, strains D2 and A14E, a large plasmid was seen in conventional gel electrophoresis plasmid profiles. Plasmid DNA was detected by pulsed-field gel electrophoresis in all isolates tested except D2, where the $4 \cdot 7-\mathrm{kb}$ plasmid had most probably run off the gel.

The large plasmids could be transferred to $S$. aureus strains by filter mating or on mouse skin at rates between $1 \times 10^{-4}$ and $1 \times 10^{-11}$ except in the case of strain D2 with which no transfer was observed. Transconjugants, including that of strain A14E, were shown to possess a single large plasmid by both conventional and density gradient centrifugation except for the $\mathrm{ByH}(1)$ transconjugant which showed a single "chromosomal" band. Strain D2 revealed bright "plasmid-like" bands on restriction endonuclease digestion of the original strain. All transconjugants plus the original D2 strain hybridised with the $4 \cdot 05-\mathrm{kb}$ probe from $S$. aureus at about $4 \mathrm{~kb}$ when the EcoRI restriction patterns were tested.

Four $S$. aureus isolates were available from patient $\mathrm{F}$ and 19 additional isolates from patient $\mathrm{By}$, but none was resistant to mupirocin.

\section{Discussion}

It appears from table I that the seven patients yielding high-level mupirocin-resistant CNS carried distinct strains except, perhaps, for patients $\mathrm{E}$ and $\mathrm{Bx}$, both of whom had an S. epidermidis strain resistant only to penicillin in addition to mupirocin and possessing only a single large plasmid. This might be regarded as rather tenuous evidence of cross-infection, but the restriction patterns shown in table II confirm that these single plasmids were indistinguishable and, in all probability, these represent a single strain. More surprising is the fact that the mupirocin resistance plasmids in the two S. epidermidis isolates from patient By differed and were also different from that in the $S$. capitis strain of that patient. Equally, the mupirocin

\section{References}

1. Noble WC. Staphylococci in the skin. In: Noble WC (ed) The skin microflora and microbial skin disease. Cambridge University Press. 1992: 135-152.

2. Hill RLR, Fisher AP, Ware RJ, Wilson S, Casewell MW Mupirocin for the reduction of colonisation of internal jugular cannulae-a randomised controlled trial. $J$ Hosp Infect 1990; 15: 311-321.

3. Boelaert JR, de Baere YA, Geernaert MA, Godard CA, van Landuyt HW. The use of nasal mupirocin ointment to prevent Staphylococcus aureus bacteraemias in haemodialysis patients: an analysis of cost-effectiveness. $J$ Hosp Infect 1991 ; 19 Suppl B: 41-46.

4. Holton DL, Nicolle LE, Diley D, Bernstein K. Efficacy of mupirocin nasal ointment in eradicating Staphylococcus aureus nasal carriage in chronic haemodialysis patients. $J$ Hosp Infect 1991 ; 17: 133-137.

5. Pignatari A, Jones RN, Barrett MR, Sesso R, Leme I, Pfaller MA. Use of antimicrobial susceptibility testing for epi- resistance plasmids in the S. epidermidis and S. hominis strains of patient $\mathrm{V}$ differed, though there was very close similarity between the plasmids of $S$. capitis and $S$. hominis isolates from these two patients.

In all but one instance the plasmids were transferable, although in some cases at low frequencies, to $S$. aureus strains. Some rates were sufficiently high $\left(1 \times 10^{-4}\right)$, to warrant the description of conjugative plasmid, these rates being typical of those for other mupirocin resistance plasmids, gentamicin resistance plasmids and others. ${ }^{10,15}$

One plasmid (strain D2) was detectable only by pulsed-field electrophoresis and, in this respect, resembled the original mupirocin resistance plasmid described in $S$. aureus $^{9}$ although the structure of the plasmid determined by $E c o$ RI restriction patterns was quite different.

The probe used was a $4 \cdot 05-\mathrm{kb} E c o \mathrm{RI}$ fragment from a plasmid in $S$. aureus shown to contain the entire mupirocin resistance gene which resembles, in some respects, the isoleucyl tRNA synthetase gene in E. coli. ${ }^{14}$ In all instances, the probe hybridised with an $E c o$ RI restriction fragment of the plasmids at $c .4 \mathrm{~kb}$ and it is probable that the resistance determinants were all the same. A great variety of structures has also been seen in mupirocin resistance plasmids in clinical strains of $S$. aureus ${ }^{9}$ and, unless the determinant is a transposon, it is difficult to account for its presumed promiscuity.

As with other antibiotic resistance determinants it may be that the normal, CNS flora of the skin acts as a reservoir of mupirocin resistance genes which are available to $S$. aureus. The mupirocin-resistance rate in staphylococci not exposed to therapeutic mupirocin is not known for a general population, although we have reported previously mupirocin resistance in both $S$. aureus and $S$. epidermidis strains collected many years prior to the therapeutic use of the antibiotic. ${ }^{9}$ This finding is important because of the resistance in potential opportunist pathogens such as $S$. epidermidis, which may cause half of the peritonitis seen in CAPD patients, and because the resistance determinants are carried on transmissible replicons which may spread to other pathogenic bacteria.

demiology and the selection of oral, parenteral and topical regimens for control of CAPD-associated Staphylococcus aureus infection. $J$ Chemother 1991; 3: 108-116.

6. Cookson BD, Lacey RW, Noble WC, Reeves DS, Wise R, Redhead RJ. Mupirocin-resistant Staphylococcus aureus. Lancet 1990; 1: 1095-1096.

7. Ludlam HA, Noble WC, Marples RR, Bayston R, Phillips I. The epidemiology of peritonitis caused by coagulasenegative staphylococci in continuous ambulatory peritoneal dialysis. J Med Microbiol 1989; 30: 167-174

8. Davies SJ, Ogg CS, Cameron JS, Poston S, Noble WC. Staphylococcus aureus nasal carriage, exit-site infection and catheter loss in patients treated with continuous ambulatory peritoneal dialysis. Peritoneal Dialysis International 1989; 9: 61-64.

9. Rahman M, Connolly S, Noble WC, Cookson BD, Phillips I. Diversity of staphylococci exhibiting high-level resistance to mupirocin. J Med Microbiol 1990; 33: 97-100.

10. Naidoo J, Noble WC. Skin as a source of transferable antibiotic 
resistance in coagulase-negative staphylococci. Zentralbl Bakteriol 1987; Suppl 16: 225-234.

11. Wilson CR, Totten PA, Baldwin JN. Rapid procedure for the detection of plasmids in Staphylococcus epidermidis. Appl Environ Microbiol 1978; 36: 368-374.

12. Sambrook J, Fitsch EF, Maniatis T. Molecular cloninga laboratory manual. Cold Spring Harbor, NY, Cold Spring Harbor Laboratory. 1989: 38-41.

13. Macrina FL, Kopecko DJ, Jones KR, Ayers DJ, McCowen
SM. A multiple plasmid-containing Escherichia coli strain: convenient source of size reference plasmid molecules. Plasmid 1978; 1 : 417-420.

14. Dyke KGH, Curnock SP, Golding M, Noble WC. Cloning of the gene conferring resistance to mupirocin in Staphylococcus aureus. FEMS Microbiol Lett 1991; 61: 195-198.

15. Rahman M, Noble WC, Cookson BD. Transmissible mupirocin resistance in Staphylococcus aureus. Epidemiol Infect 1989; 102: 261-270. 